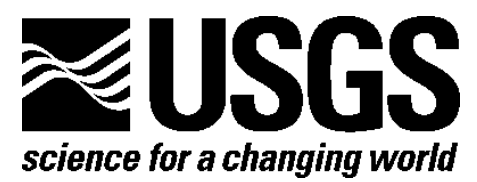

\title{
Summary of November 2010 Meeting to Evaluate Turbidite Data for Constraining the Recurrence Parameters of Great Cascadia Earthquakes for the Update of the National Seismic Hazard Maps
}

By Arthur D. Frankel

Open-File Report 2011-1310 


\section{U.S. Department of the Interior \\ KEN SALAZAR, Secretary}

\section{U.S. Geological Survey \\ Marcia K. McNutt, Director}

U.S. Geological Survey, Reston, Virginia: 2011

For product and ordering information:

World Wide Web: http://www.usgs.gov/pubprod

Telephone: 1-888-ASK-USGS

For more information on the USGS-the Federal source for science about the Earth,

its natural and living resources, natural hazards, and the environment:

World Wide Web: http://www.usgs.gov

Telephone: 1-888-ASK-USGS

Suggested citation:

Frankel, A.D., 2011, Summary of November 2010 Meeting to Evaluate Turbidite Data for Constraining the Recurrence Parameters of Great Cascadia Earthquakes for the Update of National Seismic Hazard Maps, U.S. Geologic Survey Open-File Report 2011-1310, 13 p., available at $h t t p: / / p u b s . u s g s . g o v / o f / 2011 / 1310 /$.

Any use of trade, product, or firm names is for descriptive purposes only and does not imply endorsement by the U.S. Government.

Although this report is in the public domain, permission must be secured from the individual copyright owners to reproduce any copyrighted material contained within this report. 


\section{Contents}

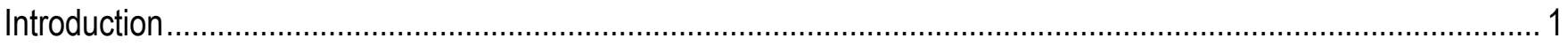

Day 1, Thursday November 18, 2010, Oregon State University, Corvallis, Oregon.............................................. 4

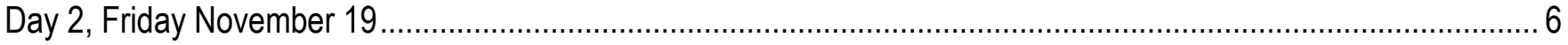

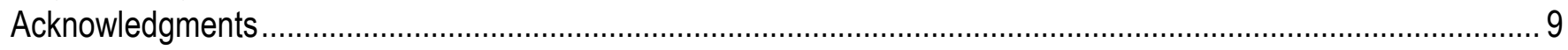

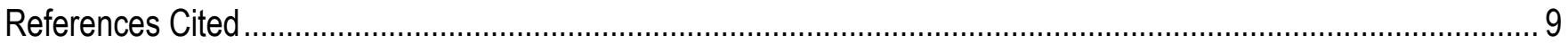

Appendix

\section{Figures}

1. Shakemap of ground-motion intensity expected for a $M_{w} 9.0$ scenario that ruptures the entire length of the Cascadia subduction zone.

2. Logic tree used for the Cascadia subduction zone in the 2008 national seismic hazard maps 


\title{
Summary of November 2010 Meeting to Evaluate Turbidite Data for Constraining the Recurrence Parameters of Great Cascadia Earthquakes for the Update of the National Seismic Hazard Maps
}

\author{
By Arthur D. Frankel
}

\section{Introduction}

This report summarizes a meeting of geologists, marine sedimentologists, geophysicists, and seismologists that was held on November 18-19, 2010 at Oregon State University in Corvallis, Oregon. The overall goal of the meeting was to evaluate observations of turbidite deposits to provide constraints on the recurrence time and rupture extent of great Cascadia subduction zone (CSZ) earthquakes for the next update of the U.S. national seismic hazard maps (NSHM). The meeting was convened at Oregon State University because this is the major center for collecting and evaluating turbidite evidence of great Cascadia earthquakes by Chris Goldfinger and his colleagues. We especially wanted the participants to see some of the numerous deep sea cores this group has collected that contain the turbidite deposits.

Great earthquakes on the CSZ pose a major tsunami, ground-shaking, and ground-failure hazard to the Pacific Northwest. Figure 1 shows a map of the Pacific Northwest with a model for the rupture zone of a moment magnitude $\mathrm{M}_{\mathrm{w}} 9.0$ earthquake on the CSZ and the ground shaking intensity (in ShakeMap format) expected from such an earthquake, based on empirical ground-motion prediction equations. The damaging effects of such an earthquake would occur over a wide swath of the Pacific Northwest and an accompanying tsunami would likely cause devastation along the Pacifc Northwest coast and possibly cause damage and loss of life in other areas of the Pacific. A magnitude 8 earthquake on the CSZ would cause damaging ground shaking and ground failure over a substantial area and could also generate a destructive tsunami.

The recent tragic occurrence of the $2011 \mathrm{M}_{\mathrm{w}} 9.0$ Tohoku-Oki, Japan, earthquake highlights the importance of having accurate estimates of the recurrence times and magnitudes of great earthquakes on subduction zones. For the U.S. national seismic hazard maps, estimating the hazard from the Cascadia subduction zone has been based on coastal paleoseismic evidence of great earthquakes over the past 5,000 years. The instrumental catalog of earthquakes is of little use for constraining the hazard of the CSZ, because there are virtually no recorded earthquakes on most of the plate interface of the CSZ. There are no historical accounts in the past 150 years of large earthquakes on most of the CSZ. Until about 20 years ago, some interpreted this lack of recent and historical earthquakes as an indicator that the subduction zone was slipping aseismically and could not produce a great earthquake.

The work of Brian Atwater and others, in the late 1980s and the 1990s (Atwater, 1987, 1992; Atwater and others, 1995; Nelson and others, 1996; Clague, 1997; Atwater and Hemphill-Haley, 1997; Atwater and others, 2004) demonstrated that submerged forests, buried soils, tsunami deposits, and liquefaction 
along and near the coast were compelling evidence of repeated great Cascadia earthquakes over at least the past 5,000 years. Atwater and Hemphill-Haley (1997) concluded from paleoseismic evidence at Willapa Bay, Washington, that great earthquakes ruptured the CSZ with an average recurrence time of about 500 years.

The date of the last great CSZ earthquake, January 26, 1700, was established from historical records of the so-called orphan tsunami in Japan that is inferred to have been produced by this earthquake (Satake and others, 1996, 2003; Atwater and others, 2005) and is consistent with tree-ring data from drowned forests in Washington and Oregon. From modeling the observations of the tsunami, Satake and others (2003) estimated a moment magnitude of about 9.0 for this earthquake.

Many other paleoseismic sites have been investigated along the Pacific Northwest coast from Vancouver Island to northern California and show evidence of great CSZ earthquakes. Nelson and others (2006) summarized the dates found from these studies and proposed correlations between sites indicating the extent of rupture for individual events. Dating of inferred tsunami deposits in Bradley Lake, Oregon by Kelsey and others (2005), as well as tsunami and subsidence evidence from Six Rivers, Oregon (Kelsey and others, 2002) and Coquille River (Witter and others, 2003), indicates that there were probably $M_{w} 8$ ruptures in the southern portion of the CSZ in addition to the $M_{w} 9$ events that rupture the whole length of the CSZ (Nelson and others, 2006).

A parallel development over the past 20 years or more is the use of deep sea turbidite deposits for identifying and dating great Cascadia earthquakes over the past 10,000 years (Adams, 1990; Goldfinger and others, 2003, 2008, in press; Goldfinger, 2011). Turbidites are sediment deposits in the deep ocean from turbidity currents, which are energetic flows of sediment and water along the continental shelf and slope. Adams (1990), using the counts of turbidites in deep-sea cores off the coast of Oregon and Washington collected and analyzed by Griggs (1969) and Griggs and others (1969), proposed that these turbidites were caused by the shaking of great Cascadia earthquakes. Part of his reasoning was that the number (13) of turbidite deposits that occurred since deposition of the Mazama Ash 7,000 years ago gave a recurrence time of about 500 years, consistent with that derived from the coastal submergence data. Adams (1990) also proposed the "confluence test" which evaluates the number of turbidites for submarine channels that form a confluence. He reported that the number of turbidites in the single downstream channel equaled the number in each of the tributary channels. He reasoned that this indicated that the turbidites in each tributary were simultaneously triggered and were, therefore, caused by a common forcing agent. He concluded that shaking from extended ruptures of great Cascadia earthquakes was the most likely cause of these turbidites.

Based on the paleoseismic evidence of past great earthquakes, the hazard from the Cascadia subduction zone was included in the 1996 U.S. NSHM (Frankel and others, 1996), which were the basis for seismic provisions in the 2000 International Building Code. These hazard maps used the paleoseismic studies to constrain the recurrence rate of great CSZ earthquakes.

Goldfinger and his colleagues have since collected many more deep ocean cores and done extensive analysis on the turbidite deposits that they identified in the cores (Goldfinger and others, 2003, 2008, in press; Goldfinger, 2011). Using their dating of the sediments and correlation of features in the logs of density and magnetic susceptibility between cores, they developed a detailed chronology of great earthquakes along the CSZ for the past 10,000 years (Goldfinger and others, in press). These 
correlations consist of attempting to match the peaks and valleys in logs of density and magnetic susceptibility between cores separated, in some cases, by hundreds of kilometers.

Based on this work, Goldfinger and others (2003, 2008, in press) proposed that the turbidite evidence indicated the occurrence of great earthquakes $\left(\mathrm{M}_{\mathrm{w}} 8\right)$ that only ruptured the southern portion of the CSZ, as well as earthquakes with about $\mathrm{M}_{\mathrm{w}} 9$ that ruptured the entire length of the CSZ. For the southernmost portion of the CSZ, Goldfinger and others (in press) proposed a recurrence time of $\mathrm{M}_{\mathrm{w}} 8$ or larger earthquakes of about 230 years.

This proposed recurrence time was shorter than the 500 year time that was incorporated in one scenario in the NSHM's. It is important to note that the hazard maps of 1996 and later also included a scenario or set of scenarios with a shorter recurrence time for $\mathrm{M}_{\mathrm{w}} 8$ earthquakes, using rupture zones that are distributed along the length of the CSZ (Frankel and others, 1996; Petersen and others, 2008). Originally, this scenario was meant to correspond to the idea that some of the 500-year averaged ruptures seen in the paleoseismic evidence could have been a series of $\mathrm{M}_{\mathrm{w}} 8$ earthquakes that occurred over a short period of time (a few decades), rather than $M_{w} 9$ earthquakes. Figure 2 shows the logic tree for the CSZ used in the 2008 NSHM's (Petersen and others, 2008). This logic tree includes whole CSZ rupture earthquakes $\left(\mathrm{M}_{\mathrm{w}}\right.$ 8.8-9.2) and partial CSZ rupture earthquakes ( $\mathrm{M}_{\mathrm{w}}$ 8.0-8.7). In this latest version of the NSHM's, the effective recurrence time of earthquakes on the CSZ with moment magnitudes greater than or equal to 8.0 over the various models is about 270 years (Petersen and others, 2008). This recurrence time applies to the entire CSZ, so that the hazard from great earthquakes was approximately equal along the whole zone, although the hazard estimates taper on the northern and southern ends of the CSZ, because of the way rupture zones of $\mathrm{M}_{\mathrm{w}} 8$ earthquakes were distributed along the strike of the CSZ.

The NSHM will be updated in 2013, as part of the standard update cycle that corresponds to the update cycle of the national model building codes that are based on the seismic hazard maps. A meeting was necessary to assemble a wide group of experts to hear Dr. Goldfinger explain his methodology for dating and correlating the turbidites and for developing the earthquake chronology.

The overall goal of the workshop was to evaluate observations of turbidite deposits to provide constraints on the recurrence times and rupture extents of great Cascadia subduction zone earthquakes for the next update of the NSHM. Before the meeting, participants were supplied with the U.S. Geological Survey (USGS) Professional Paper of Goldfinger and others (in press), as well as material from Brian Atwater and Alan Nelson. The agenda of the meeting was developed by Art Frankel, with assistance from Chris Goldfinger, Brian Atwater, Alan Nelson, Mark Petersen, and Craig Weaver. The meeting was hosted by Chris Goldfinger of Oregon State University.

We stress that it is difficult to evaluate in a two-day meeting the large amount of work that Goldfinger and his colleagues have done over the past 15 years or more. This meeting is the first step in a process that develops the inputs to the update of the national maps. The conclusions of this workshop will be discussed and possibly modified at the regional Pacific Northwest workshop for the hazard maps to be held in early 2012. Vetting new research results using informed expert opinion is an integral part of updating the national maps and does not reflect on the veracity of these results. 


\section{Day 1, Thursday, November 18, 2010, Oregon State University, Corvallis, Oregon}

The meeting started in the NORCOR Core Lab at about 9 a.m. The 28 people in attendance introduced themselves (see appendix). Frankel briefly explained the purposes of the workshop: (1) to evaluate turbidite evidence of $\mathrm{M}_{\mathrm{w}} 8.0$ or larger plate-boundary earthquakes that rupture only the southern portion of the CSZ, (2) to discuss whether the northern CSZ has evidence for $M_{w} 8.0$ or larger plate-boundary earthquakes that rupture only the northern portion of the CSZ, and (3) to discuss segmentation models for the plate boundary. He noted that this workshop was part of the process for updating the national seismic hazard maps.

Chris Goldfinger thoroughly and patiently described the overall methodology that he and his group have developed to identify, date, and correlate turbidite sequences in cores of slope and abyssal plain sediments. He discussed the origin of turbidites, methods used by his group to date the turbidites, and the correlation of magnetic susceptibility and density logs between cores. He showed that new X-ray computed tomography (CT) images of turbidite deposits improve correlations of hard-to-identify muddy turbidites.

Goldfinger noted that several cores show turbidites that record ruptures of much of the subduction zone, as well as other turbidites that record shorter partial ruptures (Hydrate Ridge and Rogue). Goldfinger stated that there are three classes of turbidite deposits that provide evidence of partial, southern rupture of the CSZ:

1. Sandy turbidites (a few)

2. Muddy turbidites that correlate well, according to Goldfinger and his colleagues, between Hydrate Ridge and Rogue cores (about 7)

3. Muddy turbidites that do not correlate as well and are identified only in Rogue cores and perhaps in cores to the south (about 10)

Goldfinger and his team had retrieved several cores from storage and placed them on tables for the workshop participants to view and discuss. Details of these cores were provided by Goldfinger and his team. There was a lively discussion about specific features in the cores, including the variation in the appearance of different turbidite deposits.

There was much discussion about the strength of the evidence in the cores. Goldfinger stated that the sandy beds visible in some of the cores mark long, large-event ruptures. Some of the sandy turbidites may also be evidence of partial CSZ ruptures. Goldfinger said that most of the partial ruptures are marked by muddy turbidites, whose signatures on the core logs are less distinct than the signatures of the sandy turbidites. Larry Phillips suggested the use of an osmotic knife that is useful for cleaning a core and making it easier to identify beds.

After 2 p.m., we went to a campus meeting room. Goldfinger showed examples on the projector screen of core photographs and lithologic, magnetic susceptibility, and density logs for cores with partial CSZ rupture turbidites. Goldfinger noted that the low-resolution projector made it difficult to see subtle differences in turbidite texture that helped to identify the partial CSZ rupture turbidites. Sometimes these differences were more easily seen when the same figures were displayed on laptops or on highresolution monitors, which were brought in for the participants.

Goldfinger noted the great thickness of muddy sediment between distinct, long-rupture turbidites in the southern cores. He stated that hemipelagic rates of sedimentation are well known in this region and that 
if all the muddy sediment was hemipelagic, the rates would yield unreasonable amounts of time between long-rupture turbidites. Therefore, he concluded that a substantial portion of the sequence consists of muddy turbidites. Similar thick, muddy sequences between the long-rupture turbidites have not been identified in northern cores by Goldfinger's group. Jake Covault stated that high-frequency climactic events could contribute to creating thick mud packages.

Jake Covault and others, asked many questions about the correlations of the magnetic and density logs between cores. Many participants noted that there were sometimes no distinctive anomalies on the magnetic and gravity logs where the muddy turbidites were inferred from differences in grain size. Anomalies on the logs larger than those that were suggested to record some muddy turbidites sometimes appear at other depths in the cores. Some workshop participants wondered what the variation in the strength of anomalies was in these logs for hemipelagic parts of the sequence.

Alan Nelson described a comparison of onshore ages for Cascadia earthquakes assembled for the meeting by Engelhart, Witter, Kelsey, himself, and others, for sites ranging from northern to southern Oregon. This group compared the timing of the onshore evidence with the timing Goldfinger determined from the turbidites of similar age (handout). Nelson noted that during certain time periods, the number of turbidite events corresponded to the number of onshore events at Bradley Lake and Sixes River. Harvey Kelsey noted that one sequence of three additional turbidites seemed to correspond with two events at Sixes River. The consensus of the workshop participants was that the number of Cascadia tsunamis and earthquakes inferred from Bradley Lake and Sixes River data for some time periods at least partially supports Goldfinger's conclusion that muddy turbidites record partial CSZ ruptures off southern Oregon.

Towards the end of the day, Goldfinger also showed evidence of subaqueous flows, possibly caused by strong ground motions from large Cascadia earthquakes, at Sanger Lake, Calif., and Effingham Bay, Vancouver Island, British Columbia.

Also towards the end of the day, Brian Atwater summarized his handout that raises questions about paleoseismic interpretations of CSZ turbidite data. He made a number of points:

(1) He noted that most of the southern CSZ turbidite evidence was collected close to the foot of the continental slope, while most from the northern CSZ was collected on fans and channels of the abyssal plain - a difference that may enable turbidite records to record smaller earthquakes in the south than in the north.

(2) Using Gary Griggs' core logs from Cascadia Channel and its tributaries, Atwater questioned the basis for John Adams' confluence test. Atwater interpreted Griggs' logs as evidence that turbidites of lower Cascadia Channel do not monitor shaking off of northern Washington.

(3) Atwater found age discordance between offshore and onshore evidence for great earthquakes on the northern CSZ. He asked whether errors in offshore correlation, as well as dating, might contribute to this discordance. 
(4) Atwater wondered whether additional $\mathrm{M}_{\mathrm{w}} 8$ earthquakes that ruptured only the northern portion of the CSZ might be represented in tsunami deposits at Discovery Bay, Washington, and near Tofino, British Columbia.

Meeting adjourned for the day at 7 p.m.

\section{Day 2, Friday, November 19}

Meeting started at 9 a.m.

Frankel started out with a description of the CSZ hazard model for the 2008 NSHM showing the logic tree displayed in the latest documentation (fig. 2; Petersen and others, 2008). There was a discussion by Ned Field and Ivan Wong about whether the $\mathrm{M}_{\mathrm{w}} 9$ and $\mathrm{M}_{\mathrm{w}} 8$ treatment in the current maps represented aleatory or epistemic uncertainty. Frankel said it was aleatory, because the $\mathbf{M}_{\mathrm{w}} 8$ 's were meant to represent a sequence in which the whole rupture of the CSZ occurred in a cascade of $\mathrm{M}_{\mathrm{w}} 8$ 's rather than a whole-rupture $M_{w} 9$. However, showing these aleatory scenarios in a logic tree format (which traditionally displays the epistemic uncertainty) causes confusion and implies that these are alternative models. This was not the intention; the figure caption mentions aleatory components in the logic tree figure. Frankel noted that the NSHM Project had not considered separate $\mathrm{M}_{\mathrm{w}} 8$ 's because quantitative information on their rates was not available until recently. The weights of the two $M_{w} 8$ and 9 scenarios add to one, because they represent different possibilities for the whole CSZ ruptures. There is an obvious need to include hazard from the $M_{w} 8$ partial CSZ rupture earthquakes found in more recent studies of onshore and offshore data. Frankel mentioned that the hazard from a cascade of $\mathrm{M}_{\mathrm{w}} 8$ earthquakes could be calculated differently, using the algorithm of Toro and Silva (2001).

Frankel compared hazard maps made with the Goldfinger and others (in press) recurrence model, based on their correlations and dates of turbidites, with the current maps. The maps using the Goldfinger and others (in press) model showed higher hazard in the southern portion of the CSZ compared to the current model. In some locations there is as much as a 50\% increase in probabilistic ground motions. He also compared hazard maps made with a recurrence model derived from the Nelson and others (2006) comparison of dated onshore evidence for great earthquakes and accompanying tsunamis to the current maps and to the maps based on Goldfinger and others (in press). The maps based on the comparison data of Nelson and others (2006) are intermediate in hazard between the current maps and the maps made with the Goldfinger and others (in press) parameters.

Gary Carver pointed out the importance of including offshore Gorda-plate earthquakes in the hazard calculation.

Frankel asked four questions to try to develop a consensus view of the workshop participants.

Question 1. Do the workshop participants agree that M9 earthquakes that ruptured the entire length of the CSZ occurred every 500-600 yr? Some workshop participants thought that some of the giant earthquakes $\left(\mathrm{M}_{\mathrm{w}}\right.$ ) ) inferred from turbidite and onshore evidence could instead be cascades of lesser, but still great earthquakes $\left(\mathrm{M}_{\mathrm{w}} 8\right)$ that sequentially ruptured the entire CSZ over periods of days, years, or even a few decades. Participants were comfortable with the 500-600 yr average recurrence time for long ruptures of the entire CSZ accomplished either by M9 or serial M8 earthquakes. Some workshop participants stated that onshore evidence of coseismic land subsidence and tsunamis, 
and offshore turbidite evidence are compatible with some events being cascades of $\mathrm{M}_{\mathrm{w}}$ 8s. Goldfinger said that the turbidite evidence did not support the idea of serial $\mathrm{M}_{\mathrm{w}} 8 \mathrm{~s}$. There was debate on whether to use the plate convergence rate as a constraint for earthquake recurrence and magnitude. Ray Weldon pointed out the Bird and Kagan (2004) study showing that there was 30\% "aseismic" slip on subduction zones on average.

Weldon, Field, and others, suggested that we use a logic tree branch with M7s to be complete and to cover more possibilities. It was unclear how to establish the rate on this branch and what weight to give it. Carver said that treating the Petrolia earthquake as an event that could occur along the rest of the CSZ was not a good idea, because there was a unique tectonic setting near the triple junction.

Question 2. How many additional M8+ earthquakes ruptured only the southern portion of the CSZ? Frankel pointed out that the Nelson and others compilation presented at the meeting implied about a 1,000 yr recurrence interval for shorter ruptures during certain periods at Bradley Lake and Sixes River. This interval is similar to the Goldfinger and others (in press) 1,000 yr recurrence time for muddy turbidites correlated between Hydrate Ridge and Rogue. Goldfinger et al. (in press) proposed that there are about 20 partial rupture events over 10,000 yr, including events that do not correlate between Hydrate Ridge and Rogue.

The workshop consensus was for 10 partial-rupture M8+ earthquakes in the southern portion of the CSZ over 10,000 yr. Workshop participants felt more comfortable that the onland data supported this recurrence of earthquakes and tsunamis, at least for certain time periods. Covault stated that without the onland evidence, he found it problematic to associate the turbidites with great Cascadia earthquakes. Given about 19 whole-CSZ ruptures over the past 10,000 years from Goldfinger's correlated sequence, this implies approximately $29 \mathrm{M}_{\mathrm{w}} 8.0$ or larger events that ruptured at least the southern portion of the CSZ over the past 10,000 yr. This number gives an average recurrence time of about $340 \mathrm{yr}$ for M8.0 or larger earthquakes on the southern CSZ. This average recurrence time includes $M_{w} 9$ earthquakes (or $\mathrm{M}_{\mathrm{w}} 8+$ cascades) that rupture the entire CSZ. Of course, this consensus of workshop participants was based on their views of the state-of-knowledge at the time of the November workshop.

Question 3. How many partial-rupture M8+ events should be considered for northern CSZ? Frankel tried to summarize Atwater's presentation materials and found about 2-3 additional events in 10,000 yr. Atwater pleaded agnostic, other than stating that there needs to be a model to represent the possibility of additional events on a mainly Canadian portion of the CSZ. Atwater said such a model would be consistent with published onshore evidence at Discovery Bay and Tofino.

Most workshop participants were convinced that the southern CSZ had a shorter recurrence time and, therefore, a higher hazard than the northern CSZ. There was no consensus of workshop participants on a preferred average recurrence time for $\mathrm{M}_{\mathrm{w}} 8+$ earthquakes that rupture only the northern portion of the CSZ.

Frankel stated that there will be many models in the next round of the hazard maps to account for the uncertainties and range of expert opinion. One model could have more hazard in the southern CSZ (higher weight), one model could have equal hazard in the north and south (lower weight), another model could have a separate northernmost zone of higher recurrence rate similar to the south. 
Question 4. What are the possible segment boundaries for the Cascadia megathrust? This question addresses whether there are preferred segment boundaries along the CSZ that will affect the lateral extent of the rupture zones of these partial CSZ rupture earthquakes. Goldfinger and Carver pointed out that Cape Blanco has been suggested as a segmentation boundary for decades, because of the age difference in subducting lithosphere along the strike of the CSZ. Other participants agreed that Cape Blanco was the most obvious potential segment boundary. So some ruptures could extend from around Hydrate Ridge south to Cape Blanco. Some rupture zones could go from Hydrate Ridge to Cape Mendocino.

Ray Wells produced a handout showing segmentation and gravity along the Nankai Trough, Japan, and Cascadia (from Wells and others, 2003). Weldon talked about segmentation recognized from uplift data and changes in episodic tremor and slip (ETS) behavior. He also thought that the southern border of Siletzia may influence rupture segmentation. Goldfinger suggested Heceta Bank and Nehalem Bank as possible segment boundaries. One relevant question was what was the maximum distance from the end of a rupture that would still produce ground motions strong enough to generate a turbidite. Goldfinger estimates this distance to be about $90 \mathrm{~km}$, based on the maximum distance of observed turbidites generated by ground motions during the 1906 San Andreas Fault rupture. Atwater stated the need to allow for a mostly Canadian segment.

Further discussion centered on future research directions that could help reduce hazard uncertainties. Petersen noted that the update of the NSHM didn't need to be done by until about December 2013. Field said that the next Uniform California Earthquake Rupture Forecast (UCERF 3) needs a CSZ rupture model by June 2012. Goldfinger said that his group will analyze additional cores within a year and will have more interpretations. Frankel said that the meeting was the start of the process for making recurrence models for CSZ. There will be discussion of the CSZ recurrence models at the regional workshop for the Pacific Northwest for the national seismic hazard maps in early 2012.

Workshop participants emphasized the value of a more systematic search of lake as well as marine deposits for evidence of CSZ ground-motion-generated deposits. Paul Johnson suggested that new cores should be collected at sites closer to the source areas of muddy turbidites, so that changes in grain size could be measured as a function of distance from sources. Covault suggested use of a laser particle size analyzer (LPSA) to better identify the muddy turbidites.

Frankel and participants thanked Goldfinger for his patient and thorough description of his work, Atwater for his careful reevaluation of core data and comparison with onland data, and the Oregon onshore geologists for their compilation of land data. Frankel thanked all the participants for their enthusiastic discussions and for their help in defining the CSZ recurrence models for the update of the national maps.

The meeting adjourned at 1 p.m. 


\section{Acknowledgments}

Chris Goldfinger graciously hosted the meeting and his careful explanations were essential to its success. I thank Brian Atwater and Alan Nelson for their editing of the text and for their comments. John Vidale provided useful comments. Pat McCrory and Holly Ryan were helpful in suggesting participants. The USGS provided funding for this meeting through the MultiHazard Demonstration Project. I thank Craig Weaver, USGS regional coordinator for the Pacific Northwest, for his support of the meeting. Brian Sherrod and Mark Petersen provided helpful reviews of this report.

\section{References Cited}

Adams, J., 1990, Paleoseismicity of the Cascadia subduction zone-Evidence from turbidites off the Oregon-Washington margin: Tectonics, v. 9, p. 569-583.

Atwater, B.F., 1987, Evidence for great Holocene earthquakes along the outer coast of Washington state: Science, v. 236, p. 942-944.

Atwater, B.F., 1992, Geologic evidence for earthquakes during the past 2,000 years along the Copalis River, southern coastal Washington: Journal of Geophysical Research., v. 97, no. B2, p. 19011919.

Atwater, B.F., and Hemphill-Haley, E., 1997, Recurrence intervals for great earthquakes of the past 3,500 years at northeastern Willapa Bay,Washington: U.S. Geological Survey Professional Paper 1576, 108 p.

Atwater, B.F., Nelson, A.R., Clague, J.L., Carver, G.A., Yamagouchi, D.K., Bobrowsky, P.T., Bourgeois, J., Darienzo, M.E., Grant, W.C., Hemphill-Haley, E., Kelsey, H.M., Jacoby, G.C., Nishenko, S., Palmer, S.P., Peterson, C.D., and Reinhart, M.A., 1995, Summary of coastal geologic evidence for past great earthquakes at the Cascadia Subduction Zone: Earthquake Spectra, v. 11, p. 1-18.

Atwater, B.F., Tuttle, M.P., Schweig, E.S., Rubin, C.M., Yamaguchi, D.K., and Hemphill-Haley E., 2004, Earthquake recurrence, inferred from paleoseismology, in Gillespie, A.R., Porter, S., and Atwater, B.F., eds, The Quaternary Period in the United States: Amsterdam, Elsevier, p. 331350.

Atwater, B.F., Musumi-Rokkaku, S., Satake, K., Yoshinobu T., Ueda, K., and Yamaguchi, D., 2005, The orphan tsunami of 1700: U.S. Geological Survey Professional Paper 1707.

Bird, P., and Kagan, Y.Y., 2004, Plate-tectonic analysis of shallow seismicity-Apparent boundary width, beta, corner magnitude, coupled lithosphere thickness, and coupling in seven tectonic settings: Bulletin of the Seismological Society of America, v. 94, p. 2380-2399.

Clague, J.J., 1997: Evidence for large earthquakes at the Cascadia subduction zone: Reviews of Geophysics, v. 35, p. 439-460.

Frankel, A., Mueller, C., Barnhard, T., Perkins, D., Leyendecker, E., Dickman, N., Hanson, S., and Hopper, M., 1996, National seismic-hazard maps-Documentation June 1996: U.S. Geological Survey Open-File Report 96-532, 110 p.

Goldfinger, C., 2011, Submarine paleoseismology based on turbidite records: Annual Reviews of Marine Sciences, v. 3, p. 35-66.

Goldfinger, C., Nelson, C.H., Johnson, J.E., and Shipboard Scientific Party, 2003, Holocene earthquake records from the Cascadia Subduction Zone and northern San Andreas Fault based on precise dating of offshore turbidites: Annual Reviews of Earth and Planetary Sciences, v. 31, p. 555577. 
Goldfinger, C., Grijalva, K., Burgmann, R., Morey, A.E., Johnson, J.E., and others, 2008, Late Holocene rupture of the northern San Andreas Fault and possible stress linkage to the Cascadia Subduction Zone: Bulletin of the Sesimological Society of America, v. 98, p. 861-889.

Goldfinger, C., Nelson, C.H., Morey, A., Johnson, J.E., Gutierrez-Pastor, J., Eriksson, A.T., Karabanov, E., Patton, J., Gracia, E., Enkin, R., Dallimore, A., Dunhill, G., and Vallier, T., in press, Turbidite event history-Methods and implications for Holocene paleoseismicity of the Cascadia Subduction Zone: U.S. Geological Survey Professional Paper 1661-F.

Griggs, G.B., 1969, Cascadia Channel-The anatomy of a deep-sea channel: Corvallis, Oregon State University, Ph.D. dissertation, 183 p.

Griggs, G.B.; Carey, A.G., Jr.; and Kulm, L.D., 1969, Deep-sea sedimentation and sediment-fauna interaction in Cascadia Channel and on Cascadia Abyssal Plain: Deep Sea Research and Oceanographic Abstracts, v. 16, p. 157-166, IN3-IN6, 167-170, doi:10.1016/00117471(69)90071-0.

Kelsey, H.M., Witter, R.C., and Hemphill-Haley, E., 2002, Plate-boundary earthquakes and tsunamis of the past 5,500 years, Sixes River estuary, southern Oregon: Geological Society of America Bulletin, v. 114, p. 298-314.

Kelsey, H.M., Nelson, A.R., Hemphill-Haley, E., and Witter, R.C., 2005, Tsunami history of an Oregon coastal lake reveals a 4,600 year record of great earthquakes on the Cascadia subduction zone: Geological Society of America Bulletin, v. 117, p.1009-1032.

Nelson, A.R., Shennan, I., and Long, A.J., 1996, Identifying coseismic subsidence in tidal-wetland stratigraphic sequences at the Cascadia subduction zone of western North America: Journal of Geophysical Resaerch, v. 101, no. B3, p. 6115-6135.

Nelson, A.R., Kelsey, H.M., and Witter, R.C., 2006, Great earthquakes of variable magnitude at the Cascadia subduction zone: Quaternary Research, v. 65, p. 354-365.

Petersen, M., Frankel, A., Harmsen, S., Mueller, C., Haller, K., Wheeler, R., Wesson, R., Zeng, Y., Boyd, O., Perkins, D., Luco, N., Field, E., Wills, C., and Rukstales, K., 2008, Documentation for the 2008 update of the United States National Seismic Hazard Maps: U.S. Geological Survey Open-File Report 2008-1128, 61 p.

Satake, K., Shimazaki, K., Tsuji, Y., and Ueda, K., 1996, Time and size of a giant earthquake in Cascadia inferred from Japanese tsunami record of January 1700: Nature, v. 379, p. 246-249.

Satake, K., Wang, K., and Atwater, B.F., 2003, Fault slip and seismic moment of the 1700 Cascadia earthquake inferred from Japanese tsunami descriptions: Journal of Geophysical Research, v. 108, no. B11, 2535, doi:10.1029/2003JB002521.

Toro, G.R., and Silva, W.J., 2001, Scenario earthquakes for Saint Louis, MO, and Memphis,TN, and seismic hazard maps for the central United States region including the effect of site condition: Reston, Virginia, technical report to U.S. Geological Survey, under Contract 1434-HQ-97GR02981, http://www.riskeng.com/PDF/Scen_CEUS_Rept.pdf .

Wells, R.E., Blakely, R.J., Sugiyama, Y., Scholl, D.W., and Dinterman, P.A., 2003, Basin-centered asperities in great subduction zone earthquakes-A link between slip, subsidence, and subduction erosion?: Journal of Geophysical Research, v. 108, no. B10, 2507, doi:10.1029/2002JB002072.

Witter, R.C., Kelsey, H.M., and Hemphill-Haley E., 2003, Great Cascadia earthquakes and tsunamis of the past 6,700 years, Coquille River estuary, southern coastal Oregon: Geological Society of America Bulletin, v. 115, p. 1289-1306. 


\section{Appendix}

List of workshop participants in alphabetical order.

Brian Atwater, USGS

Jody Bourgeois, University of Washington

Gary Carver, private consultant

Jake Covault, USGS

Ned Field, USGS

Art Frankel, USGS

Chris Goldfinger, Oregon State University

Paul Johnson, University of Washington

Harvey Kelsey, Humboldt State University

Roland LaForge, Fugro Consultants, Inc.

Ian Madin, Oregon Department of Geology and Mineral Industries

Alan Nelson, USGS

Mark Petersen, USGS

Larry Phillips, USGS

Ann Morey Ross, Oregon State University

Gordon Seitz, California Geological Survey

Ben Sheets, University of Washington

Brian Sherrod, USGS

Guillaume St. Onge, University of Quebec at Rimouski

John Vidale, University of Washington

Craig Weaver, USGS

Tim Walsh, Washington State Department of Natural Resources

Ray Weldon, University of Oregon

Ray Wells, USGS

Chesley Williams, Risk Management Solutions, Inc.

Rob Witter, Oregon Department of Geology and Mineral Industries

Ivan Wong, URS Corporation

Robert Yeats, private consultant 


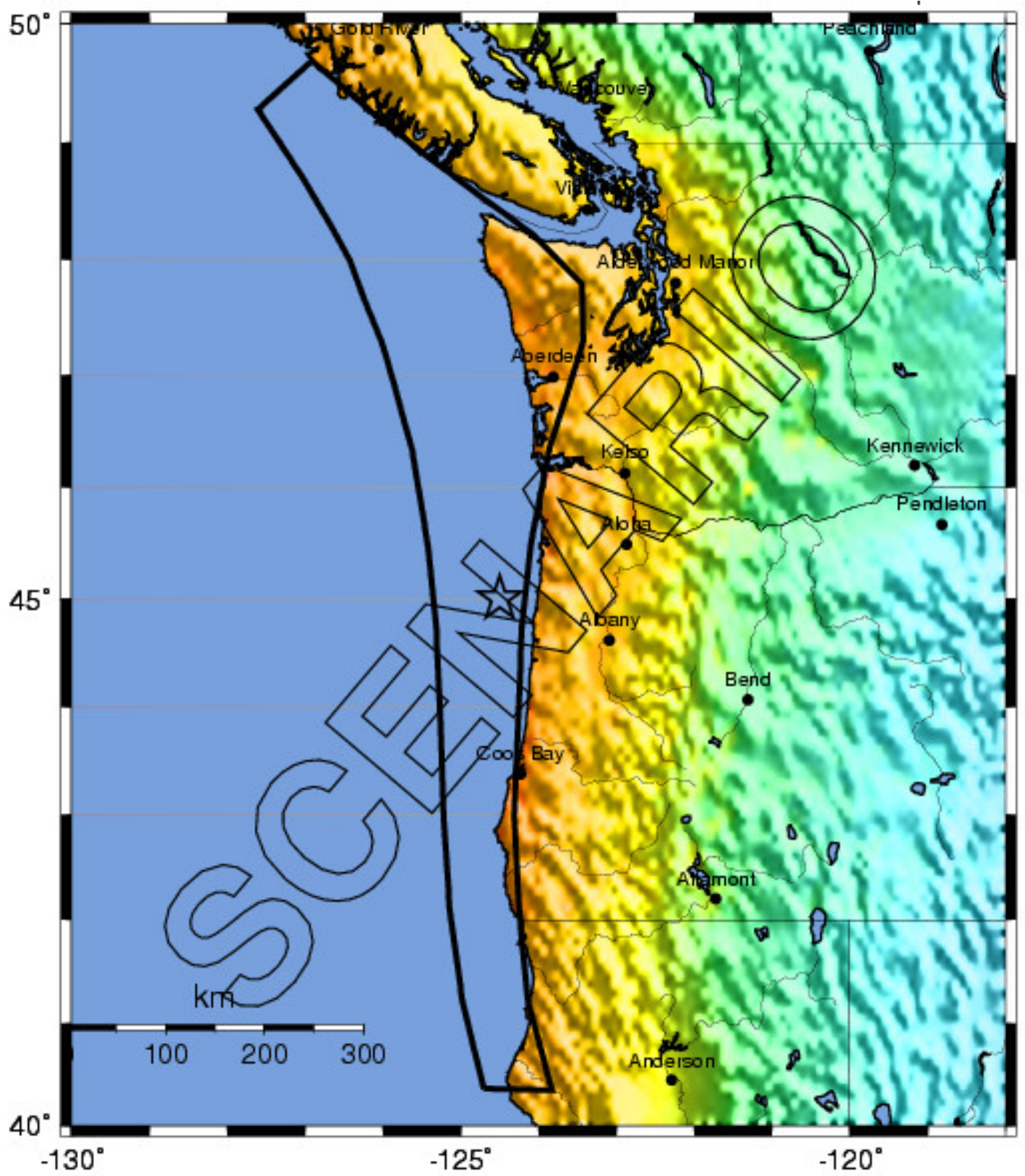

PLANNING SCENARIO ONLY .- Map Version 3 Processed Tue Sep 29, 2009 03:43:47 PM MDT

\begin{tabular}{|c|c|c|c|c|c|c|c|c|c|}
\hline $\begin{array}{l}\text { PEPCEIVED } \\
\text { SHAKIMGG }\end{array}$ & Notfelt & Weak & Light & Moderate & Strong & Very stiong & Severe & Violent & Extreme \\
\hline $\begin{array}{l}\text { POTERTIAL } \\
\text { DAMAGE }\end{array}$ & none & none & none & Very ight & Light & Moderate & Modera te/Heavy & Heavy & Very Heavy \\
\hline PEAK ACC $(\% \mathrm{Fg})$ & $<.17$ & $.17-1.4$ & $1.4-3.9$ & $3.9-9.2$ & $9.2-18$ & $18 \cdot 34$ & $34-65$ & $65-124$ & $>124$ \\
\hline PEAK VEL L $(\mathrm{c} m / \mathrm{s})$ & $<0.1$ & $0.1-1.1$ & $1.1-3.4$ & $3.4-8.1$ & $8.1-16$ & $16-31$ & $31-60$ & $60-116$ & $>116$ \\
\hline $\begin{array}{l}\text { INSTRUMENTAL } \\
\text { INTENSTYY }\end{array}$ & I & II-III & IV & V & VI & VII & VIII & IX & $X_{t}$ \\
\hline
\end{tabular}

Figure 1. Shakemap of ground-motion intensity expected for a $M_{w} 9.0$ scenario that ruptures the entire length of the Cascadia subduction zone. Solid outline denotes rupture zone used in ground-motion calculations. 


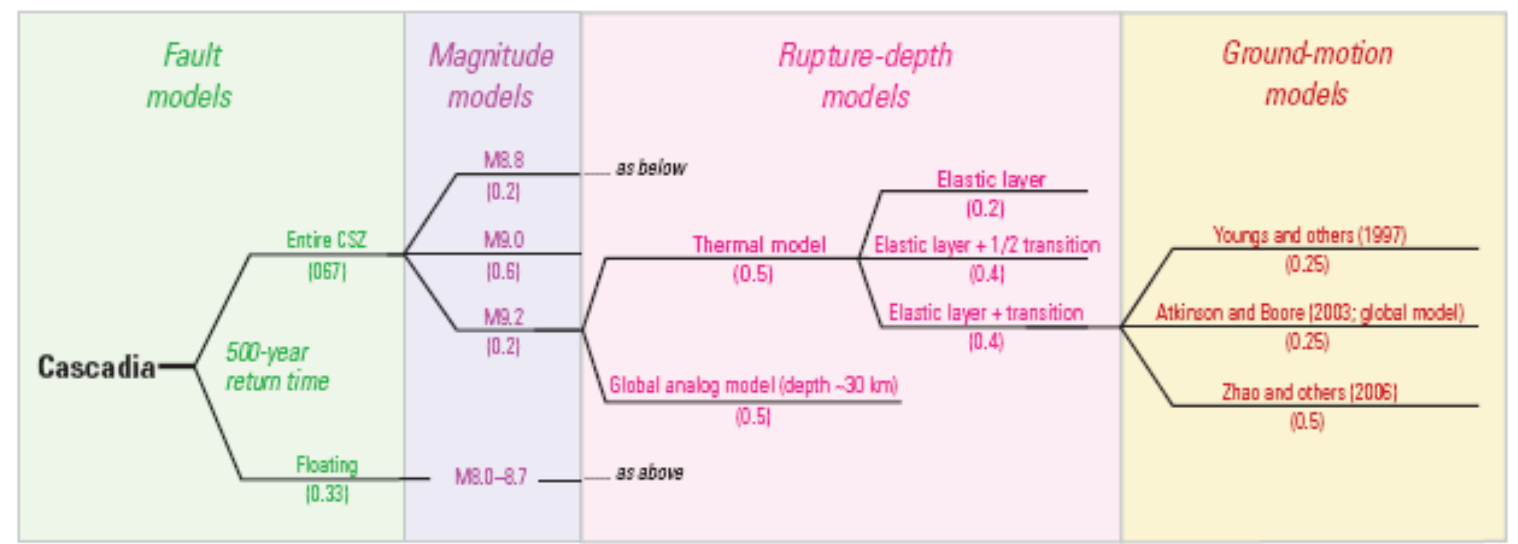

Figure 2. Logic tree used for the Cascadia subduction zone in the 2008 national seismic hazard maps (from Petersen and others, 2008). This diagram contains epistemic and aleatory uncertainty. 